\title{
Use of Sediment and Algae for Biomonitoring the Coast of Honaïne (Far West Algerian)
}

\author{
Hadil Allam*, Amaria Aouar, Wacila Benguedda, Réda Bettioui \\ Laboratoire "Valorisation des Actions de l'Homme pour la Protection de l'Environnement et Application en \\ Santé Publique", Department d'Ecologie et Environnement, Faculté SNV-STU, Université de Tlemcen, \\ Tlemcen, Algérie \\ Email: *allamhadil@hotmail.fr
}

Received 8 January 2016; accepted 12 March 2016; published 15 March 2016

Copyright (C) 2016 by authors and Scientific Research Publishing Inc.

This work is licensed under the Creative Commons Attribution International License (CC BY). http://creativecommons.org/licenses/by/4.0/

(c) (i) Open Access

\begin{abstract}
Concentrations of $\mathrm{Fe}, \mathrm{Cu}, \mathrm{Pb}, \mathrm{Zn}, \mathrm{Cd}$ and $\mathrm{Ni}$ were determined in the red alga Corallina officinalis (Linnaeus, 1758), the green alga Ulva lactuca (Linnaeus, 1753) and sediment sampled in four stations of the coastline of Honaïne (extreme Western Algeria). The abundance of metal concentrations in algae and sediment samples, is in the following order: $\mathrm{Fe}>\mathrm{Zn}>\mathrm{Pb}>\mathrm{Ni}>\mathrm{Cu}>\mathrm{Cd}$. $\mathrm{The}$ schematic representation by PCA reflects a strong correlation of the corallina with $\mathrm{Cd}$ and $\mathrm{Pb}$, the ulva with $\mathrm{Zn}$ and $\mathrm{Ni}$ and sediment with $\mathrm{Cu}$ and $\mathrm{Fe}$, in addition, to homogeneity of rehearsals in each matrix. The results of this study validate the use of these species as reliable tools for biomonitoring of metal pollution of coastal ecosystems, even if the levels of heavy metals in sediment and algae from the coastline of Honaïne are in general, very low compared with those from other geographic areas and by guidelines.
\end{abstract}

\section{Keywords}

Biomonitoring, Metal Pollution, Corallina officinalis, Ulva lactuca, Sediments, Coastline Honaïne

\section{Introduction}

Pollution levels in marine environments by heavy metals can be estimated by analysis of water, sediment and marine organisms [1]. In this context, the chlorobiontes and the rhodobiontes have been studied extensively for their potential use as bioindicators for metallic contamination [2], because they are able to absorb heavy metals from water and sediment and to disseminate them within their cytoplasmic cells [3].

\footnotetext{
*Corresponding author. nitoring the Coast of Honaïne (Far West Algerian). Open Journal of Ecology, 6, 159-166.

http://dx.doi.org/10.4236/oje.2016.64016
}

How to cite this paper: Allam, H., Aouar, A., Benguedda, W. and Bettioui, R. (2016) Use of Sediment and Algae for Biomo- 
Many studies focus on species of the genus Ulva, and numerous studies have concluded the trapping properties of metals in red algae and corallina precisely in as [4]-[6]. Furthermore, sediment is an indicator for the investigation of pollution by heavy metals because it consists of a mixture of organic and inorganic compounds [7].

In this study, concentrations of $\mathrm{Fe}, \mathrm{Cu}, \mathrm{Pb}, \mathrm{Zn}, \mathrm{Cd}$ and $\mathrm{Ni}$ in two species of algae Ulva lactuca and Corallina officinalis in addition to sediment sampled on the coast of Honaïne were determined by atomic absorption spectrophotometer flame and relations between biota and analyzed heavy metals have been evaluated.

\section{Material and Methods}

\subsection{Sampling}

Our choice fell on the coast of Honaïne with four stations respectively from west to east: 1 -Ouled Saleh; 2 Lebsit; 3-Tafsout; and 4-Agla (Figure 1).

Biota sampling depends on their availability in the stations, where: Sediments were sampled from stations 3 and 4 , the green algae from station 1 and 2 while the red algae were sampled from all stations.

\subsection{Chemical Analysis}

Upon arrival at the laboratory, algae are rinsed in doubly distilled water, cleaned of their epibionts and sediment. Dried algae are then crushed and sieved (mesh $<63 \mu \mathrm{m}$ size). Samples of $1 \mathrm{~g}$ of sediment are attacked hot twice by a mixture $\left(2 \mathrm{ml} \mathrm{HNO}_{3}+6 \mathrm{ml} \mathrm{HCl}\right)$ until complete evaporation.

For algae, aliquots fractions about $0.875 \mathrm{~g}$ dry weight were digested with $5 \mathrm{ml}$ of perchloric acid $\mathrm{HClO}_{4}$ at $80^{\circ} \mathrm{C}(1 \mathrm{~h})$, the temperature is high at $150^{\circ} \mathrm{C}$ until complete evaporation, then subjected to an attack by aqua regia ( $3 \mathrm{ml} \mathrm{HCl}+1 \mathrm{ml} \mathrm{HNO}_{3}$ ) for $8 \mathrm{~h}$. The digests obtained will be adjusted to $25 \mathrm{ml}$ of doubly distilled water.

The determination of the six metallic elements $(\mathrm{Fe}, \mathrm{Cu}, \mathrm{Pb}, \mathrm{Zn}, \mathrm{Cd}$ and $\mathrm{Ni}$ ) is achieved using an atomic absorption spectrophotometer flame (AI AURORA 1200; air-acetylene flame).

\subsection{Statistical Analysis}

The interstations and interspecies variability are evaluated by using the Student $t$ test, ANOVA1 and ANOVA2, in addition to HSD Tukey's test. Analysis of correlation between the parameters studied (stations and species) is processed by principal component analysis PCA and dendrograms. The data have been processed using Minitabv 16 software.

The following equation was used to calculate the biota-sediment accumulation factor (BSAF) [8].
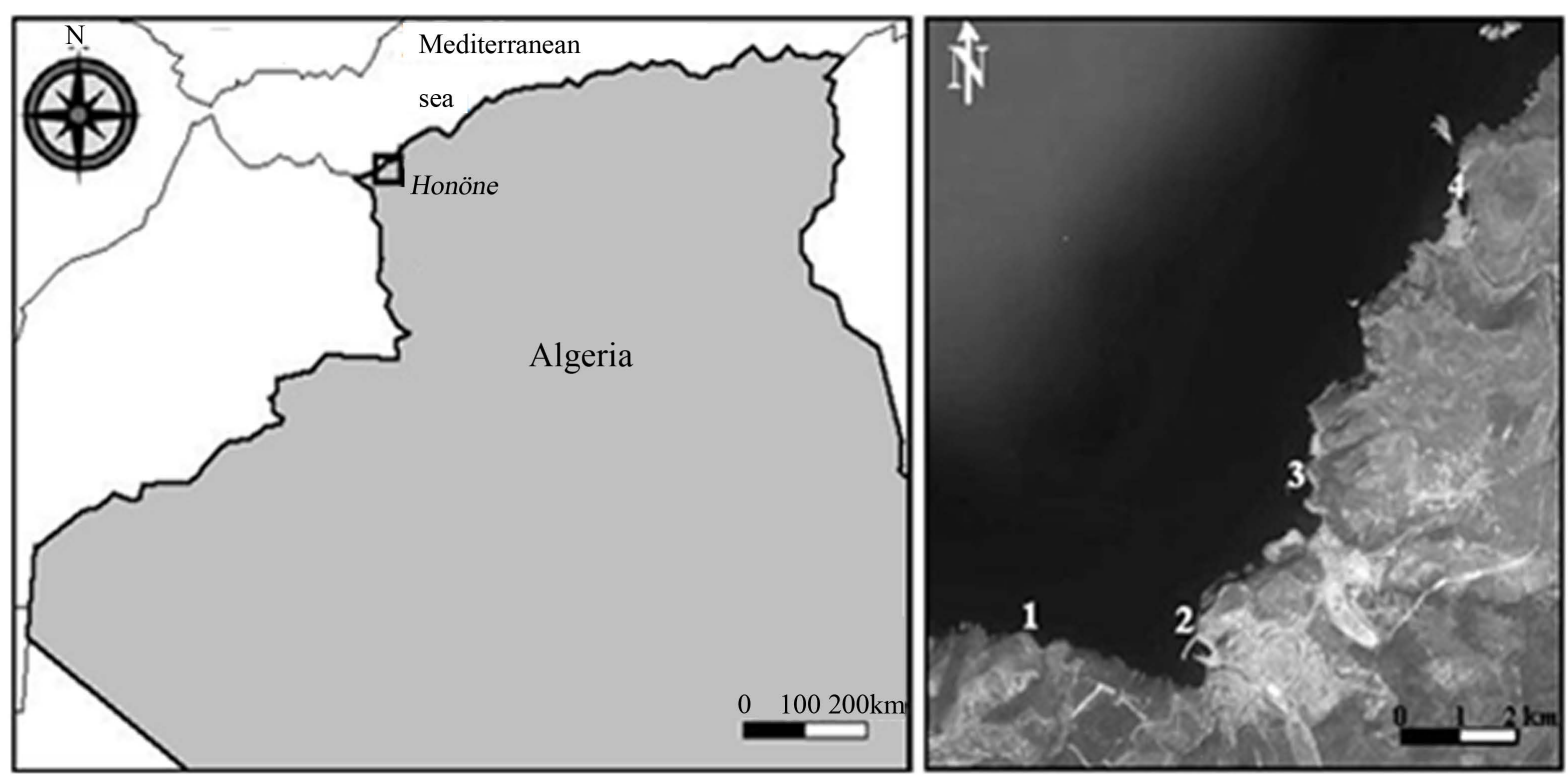

Figure 1. Location map of the study area and sampling stations. 


$$
\left.\mathrm{BSAF}=\mathrm{C}_{\text {org }} \text { (dry weight }\right) / \mathrm{C}_{\text {sed }} \text { (dry weight); }
$$

where $\mathrm{C}_{\text {org }}$ is the concentration of heavy metal in organism and $\mathrm{C}_{\text {sed }}$ is the concentration of heavy metal in sediment.

\section{Results}

The results of chemical analysis in the samples of sediment and algae analyzed are presented in the following tables:

Concerning sediment, Agla station recorded high $\mathrm{Fe}, \mathrm{Cu}$ and $\mathrm{Zn}$ levels (Table 1), are significantly higher than in Tafsout (Fe and $\mathrm{Cu}: p<0.01$, Zn: $p<0.05$ ). In contrast, $U$. lactuca and C. officinalis, and using the Student's $\mathrm{t}$ test and ANOVA 1, it was observed that the concentrations of metals in the same specie showed no significant differences between the study sites ( $p>0.05)$, which has been found by [11].

The comparison of the two species of algae and sediment by using ANOVA1 and Tukey, shows significant differences in levels for all tested metals $(p<0.01)$, resulting in the following accumulation orders of accumulation:

Fe: Sediment $>>$ ulva $\approx$ corallina; $\mathrm{Cu}$ : Sediment $>$ ulva $\approx$ corallina; $\mathrm{Pb}$ : Corallina $>$ sediment $>$ ulva;

Zn: Sediment $\approx$ corallina $>$ ulva; Cd: Corallina $\approx$ sediment $\approx$ ulva; Ni: Corallina $\approx$ sediment $>$ ulva.

Furthermore, ANOVA2 (calculated between ulva and corallina on the one hand, and between sediment and corallina on the other hand) demonstrates the absence combined effects "station" and "specie" to the averages of the metal levels in both species and sediment for all metals $(p>0.05)$.

Calculation of biosediment accumulation factor for corallina show high values obtained for $\mathrm{Cd}, \mathrm{Pb}$ and $\mathrm{Ni}$ (BSAF > 1), the maximum value of BSAF (1.52) was observed for $\mathrm{Cd}$, and the minimum value of BSAF (0.029) for Fe.

Correlations between metals, calculated in sediment and the two algae were evaluated by the application of the PCA. The eigenvalues of the PCA, the circle of correlation and factor maps are represented below (Figure 2 and Figure 3).

Examination of the factorial design and the dendrograms shows a positive correlation highly significant (coefficient of the synergistic interaction between heavy metals) consisting in well correlated descriptors between them, it is the Fe-Cu pair in surface sediment, $\mathrm{Pb}-\mathrm{Cd}$ in the corallina and $\mathrm{Zn}-\mathrm{Ni}$ in ulva. These high correlation coefficients in pairs (Figure 2 and Figure 3) raise the hypothesis of a common contamination, a homogeneous distribution, and/or a similar behaviour of these elements to the physicochemical process occurring in the environment [12].

Thus, both sedimentary levels of Agla and Tafsout with similar chemical characteristics have tended to be placed to positions nearby on the plane which bears almost all of the information (Figure 2 and Figure 3).

At the level of sediment, $\mathrm{Fe}$ and $\mathrm{Cu}$, indeed, show a geochemical behaviour often close. It is interesting revealing especially the correlation between $\mathrm{Fe}$ and $\mathrm{Cu}$, which translates, in addition to their common origin [13].

The ulva for its part, its samples from the stations Ouled Saleh and Lebsit are on the same axis correlated with $\mathrm{Zn}$ and $\mathrm{Ni}$, which poses the hypothesis of a common source of these metals, which would probably be seawater. This trend indicates that this pair of metals exist in regular proportions in plant tissues, probably as a result of controlled accumulation process [14].

Furthermore, examination of the correlation matrix between variables (Figure 4), revealed the presence in the corallina of a positive significant correlation between $\mathrm{Cd}$ and $\mathrm{Pb}$ which may have a common source which is

Table 1. Concentrations of heavy metals in sediments samples (average \pm standard deviation) expressed in $\mu \mathrm{g} \cdot \mathrm{g}^{-1}$ of dry weight.

\begin{tabular}{ccccccc}
\hline & \multicolumn{5}{c}{ Concentrations $\mathrm{x} \pm \mathrm{S} . \mathrm{D}\left(\mu \mathrm{g} \cdot \mathrm{g}^{-1}\right)$} \\
\cline { 2 - 6 } Stations & $\mathrm{Fe}$ & $\mathrm{Cu}$ & $\mathrm{Pb}$ & $\mathrm{Zn}$ & $\mathrm{Cd}$ & $\mathrm{Ni}$ \\
\hline Tafsout & $999.16 \pm 314.76$ & $0.85 \pm 0.25$ & $3.06 \pm 4.41$ & $0.72 \pm 2.04$ & $0.36 \pm 0.54$ \\
Agla & $1406.25 \pm 423.29$ & $1.11 \pm 0.2$ & $2.78 \pm 5.89$ & $0.53 \pm 1.05$ & $0.16 \pm 0.05$ \\
Guidelines $^{*}$ & 40,800 & 30.8 & 26.0101 & 0.153 \\
\hline
\end{tabular}

*[9]. 


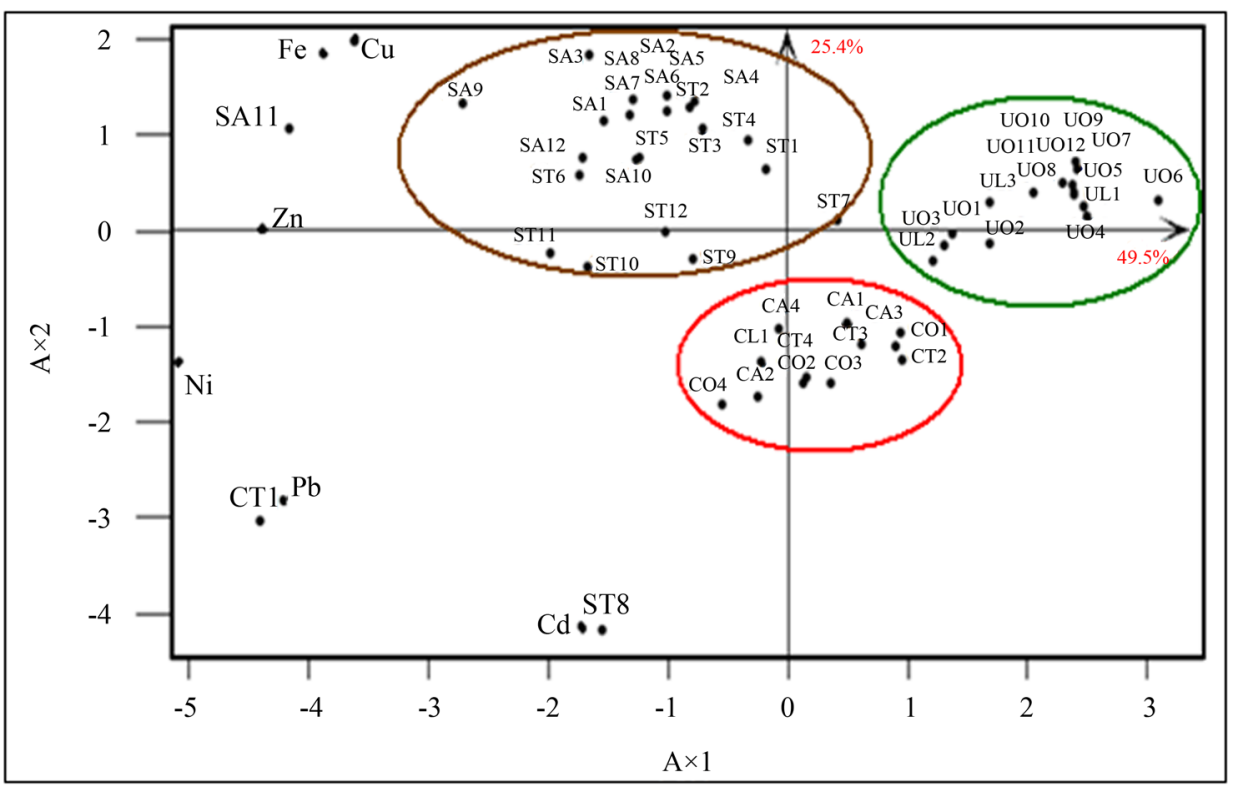

Figure 2. Factorial design created by the first two axes of the principal components analysis calculated from the metal concentrations of the different stations of the coastline of Honaïne.

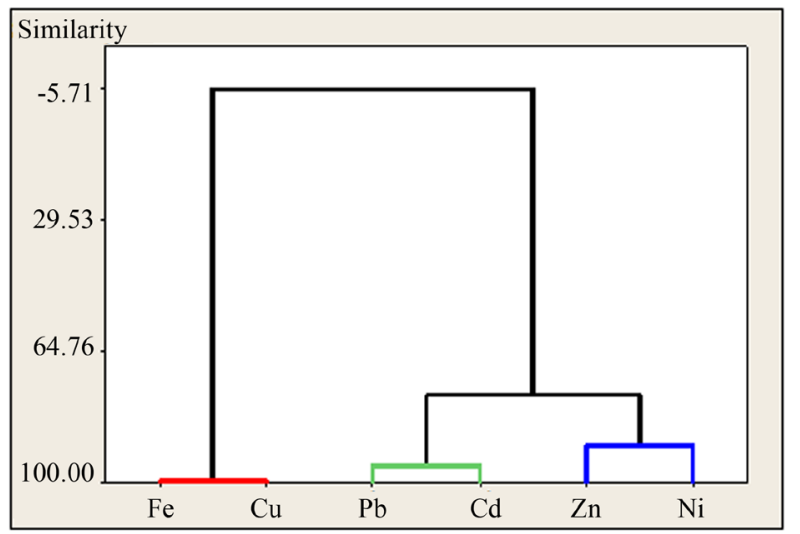

Figure 3. Dendrogram (euclidian distances) obtained from the matrix of concentrations of heavy metals in different biota studied (sediments, corallina and ulva) from coastal Honaïne.

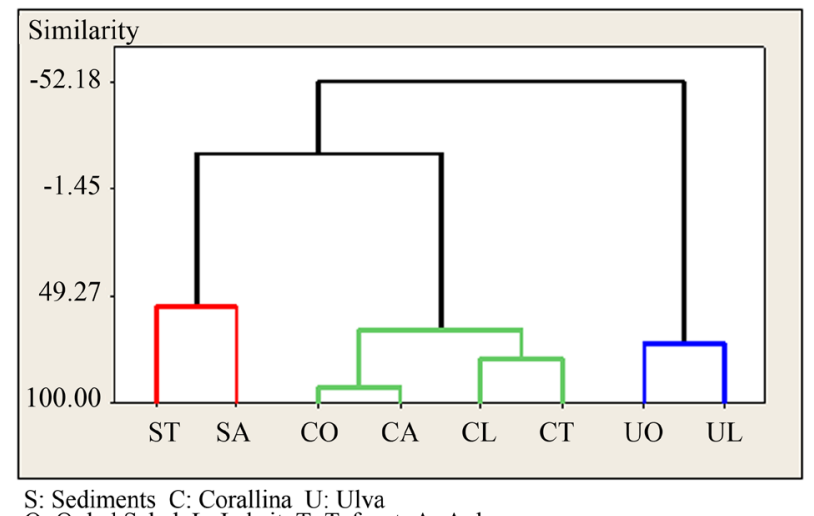

S: Sediments C: Corallina U: Ulva

Figure 4. Dendrogram (euclidian distances) obtained from the matrix of concentrations of heavy metals in different biota studied (sediments, corallina and ulva) from coastal Honaïne. 
sediment or seawater, on the other hand, a negative correlation between $\mathrm{Zn}$ and $\mathrm{Pb}$ in this alga, may indicate that they are competing for the binding sites of the alga [15], or they are transported in these stations from different sources and follow a pattern of distribution [16].

On the other hand, the trend of BSAF in Corallina officinalis was in the ordre: $\mathrm{Cd}>\mathrm{Pb}>\mathrm{Ni}>\mathrm{Cu}>\mathrm{Zn}>\mathrm{Fe}$. The mean concentrations of heavy metals in this alga were generally lower than the sediment, except nonessential elements $\mathrm{Cd}, \mathrm{Pb}$ and $\mathrm{Ni}$ (Table 2).

\section{Discussion}

A tendency to an iron content higher than that of all metals was observed along the coastline of Honaïne, in agreement with other works on algae [17] [18]. Both algae and sediment from the Coast of Honaïne accumulate Fe in the sequence: $\mathrm{Fe}>\mathrm{Zn}>\mathrm{Pb}>\mathrm{Ni}>\mathrm{Cu}>\mathrm{Cd}$, this order is in agreement with finding of [19] in the intestine of sea urchin Paracentrotus lividus from the same locality (Honaïne coast). This could be due to the fact that these species of algae are contained in the diet of the sea urchin.

According to [18], who showed that Fe and most other trace elements which are bioaccumulated in algal species have a common source ambient sediment, which explains similar trends of metal accumulation in algae and sediment.

In algae, iron is the most abundant heavy metal in their samples. The higher iron levels is located in the green alga U. lactuca (69.31 $\mu \mathrm{g} \cdot \mathrm{g}^{-1}$ in Agla), while the red alga C. officinalis contains less Fe (34.94 $\mu \mathrm{g} \cdot \mathrm{g}^{-1}$ average), these results are in agreement with those found in the Black Sea [20].

Thus, the higher Fe concentrations recorded in sediment, especially in Agla may be related to the structure of the silicates which form part of their major components [21].

The range of values for copper in Ulva lactuca sampled from uncontaminated sites is 0.1 to $3 \mu \mathrm{g} \cdot \mathrm{g}^{-1} \mathrm{~d} . \mathrm{w}$ [22], while the values of heavily contaminated sites extend from 14 to $134 \mu \mathrm{g} \cdot \mathrm{g}^{-1} \mathrm{~d} . \mathrm{w}$ [22] [23].

Based on these data, the range of the copper levels recorded in U. lactuca indicates that stations Ouled Saleh and Agla are in good ecological status for copper.

Among 11 species of algae, between other Corallina mediterranea, C. officinalis (red algae) and U. lactuca, this last present the highest accumulation for $\mathrm{Cd}, \mathrm{Fe}, \mathrm{Ni}, \mathrm{Pb}$ and $\mathrm{Zn}$ [6]. [24] demonstrate that ulva has been proved to be the greatest accumulator of $\mathrm{Cu}$. In our study, we were able to confirm these results for $\mathrm{Fe}$ and $\mathrm{Cu}$, only.

In this study, the red alga recorded the highest content of $\mathrm{Pb}\left(3.43 \mu \mathrm{g} \cdot \mathrm{g}^{-1}\right)$ compared to green algae and sediment. This agrees with the results of [25] from Alexandria (Egypt); [26] from Ghazaouet for Corallina officinalis and [27] from Jijel on other calcified red algae: Corallina mediterranea and Jania rubens from Algeria. This is may be due to the affinity of $\mathrm{Pb}$ to the calcified structures [28].

Indeed, the maximum value of $\mathrm{Pb}$ in sediment found in the station Tafsout (Table 1), may be related to the presence of large amounts of calcium carbonate grains [29].

The mean levels of $\mathrm{Zn}$ at ulva vary between 2.81 and $3.54 \mu \mathrm{g} \cdot \mathrm{g}^{-1}$, while the range of mean concentrations of

Table 2. Concentrations of heavy metals in algae samples (average \pm standard deviation) expressed in $\mu \mathrm{g} \cdot \mathrm{g}^{-1}$ of dry weight.

\begin{tabular}{|c|c|c|c|c|c|c|c|}
\hline \multirow{2}{*}{ Stations } & \multirow{2}{*}{ Species } & \multicolumn{6}{|c|}{ Concentrations $x \pm$ S.D $\left(\mu g . g^{-1}\right)$} \\
\hline & & $\mathrm{Fe}$ & $\mathrm{Cu}$ & $\mathrm{Pb}$ & $\mathrm{Zn}$ & Cd & $\mathrm{Ni}$ \\
\hline \multirow{2}{*}{ Ouled Saleh } & Corallina officinalis & $37.51 \pm 14.13$ & $0.35 \pm 0.1$ & $3.56 \pm 0.6$ & $4.23 \pm 0.57$ & $0.37 \pm 0.09$ & $1.91 \pm 0.26$ \\
\hline & Ulva lactuca & $68.35 \pm 26.96$ & $0.45 \pm 0.1$ & $1.44 \pm 0.36$ & $2.81 \pm 0.54$ & $0.15 \pm 0.08$ & $0.82 \pm 0.17$ \\
\hline \multirow{2}{*}{ Lebsit } & Corallina officinalis & $17.78 \pm 5.87$ & $0.42 \pm 0.19$ & $3.29 \pm 0.48$ & $4.89 \pm 0.61$ & $0.36 \pm 0.07$ & $2.44 \pm 0.97$ \\
\hline & Ulva lactuca & $69.31 \pm 22.82$ & $0.46 \pm 0.1$ & $2.2 \pm 0.76$ & $3.54 \pm 0.78$ & $0.16 \pm 0.098$ & $0.58 \pm 0.29$ \\
\hline Tafsout & Corallina officinalis & $36.34 \pm 12.64$ & $0.45 \pm 0.22$ & $3.96 \pm 0.85$ & $5.31 \pm 3.28$ & $0.45 \pm 0.23$ & $2.36 \pm 1.5$ \\
\hline Agla & Corallina officinalis & $48.17 \pm 35.72$ & $0.43 \pm 0.12$ & $3.35 \pm 0.39$ & $4.16 \pm 0.64$ & $0.35 \pm 0.04$ & $1.86 \pm 0.55$ \\
\hline Guidelines* & Guidelines ${ }^{*}$ & 497 & 23.2 & 0.574 & 128 & 0.0173 & 0.571 \\
\hline \multicolumn{2}{|c|}{ BSAF (C. officinalis) } & 0.029 & 0.42 & 1.2 & 0.9 & 1.52 & 1.033 \\
\hline
\end{tabular}

${ }^{*}$ [10]. 
zinc, announced in the algae from non contaminated sites is 0.5 to $23 \mu \mathrm{g} \cdot \mathrm{g}^{-1} \mathrm{~d} . \mathrm{w}$ [22], which explains the coastline Honaïne is not polluted at least for this metal.

Several authors found that $\mathrm{Zn}$ is easily accumulated by ulva compared with coralline [5] [7].

In this study, it is noted to the contrary, where a preferential accumulation of Zn Corallina officinalis relative to Ulva lactuca, which is in agreement with the results reported by [6] [27].

In Lebsit, as in Kavala harboor (Greece) [30], where there is strong evidence of domestic wastewater, the amount of Cd in both algal species is very low $\left(0.15 \mu \mathrm{g} \cdot \mathrm{g}^{-1}\right)$. Cd levels obtained in the corallina from the Tafsout may be related to the abundance of this metal in sediment [31].

Mean concentrations of cadmium in sediment of the coastline of Honaïne show a maximum value of 0.36 $\mu \mathrm{g} \cdot \mathrm{g}^{-1}$ recorded in the station Tafsout. While in the station Agla, recorded content does not exceed $0.16 \mu \mathrm{g} \cdot \mathrm{g}^{-1}$, this can be from the presence of a large amount of grains of calcium carbonate in sediment [29].

Metal concentrations in different species of algae can reflect their morphology, with those who have a larger surface with more internal contents. Species with long lifespan (annual or perennial e.g. Corallina sp.) will have the opportunity to accumulate metals to a higher degree. Growth rates may affect accumulation patterns: with fast-growing algae (e.g. Ulva) are lower concentrations [4].

Because it may be due to the fact that the species Ulva is unable to integrate high concentrations of these metals. Alternatively, it reduces the toxicity of metals by a biochemical process [23], or by regulation of the cations, which can have a mechanism by which the permeability of the cells to cations is reduced [32].

On the other hand, deficiency of essential elements $\mathrm{Fe}$ and $\mathrm{Cu}$ in Corallina officinalis can be explained by the fact that the high percentage of carbonate of calcium in corallina algae causes a lower proportion of metabolic tissues and a low metabolic rate [33], similarly, Corallina sp. was reported to show a lower metal values compared to non calcified algae accumulation [7] [34] at least for $\mathrm{Fe}$ and $\mathrm{Cu}$.

The BSAF is a parameter which describes the accumulation of sediment-associated organic compounds or metals into tissues of ecological receptors [35]. In this study, the efficiency of metal bioaccumulation in Corallina officinalis was evaluated by calculating the BSAF, which is defined as the ratio between the metal concentration in organisms and that in the sediment [8].

The corallina accumulate higher concentrations of Cd than in the sediment, it is in agreement of finding of [26] from Béni Saf (Algeria).

The mean concentractions of heavy metals in this specie were generally much lower than in sediment, except $\mathrm{Cd}, \mathrm{Pb}$ and $\mathrm{Ni}$, which indicate that this metal is easily accumulated in C. officinalis. The calculated values of BSAF for $\mathrm{Cd}, \mathrm{Pb}$ and $\mathrm{Ni}$ are much higher than 1, suggesting a higher rate of accumulation of cadmium especially in this specie.

During present research, lowest value of BSAF was for Fe which is explained by higher levels of this metal in the sediment.

In this case, water probably acts as an additional source of $\mathrm{Cu}, \mathrm{Zn}$ and $\mathrm{Fe}$ in the corallina.

The metal concentrations found in sediment are below the maximum permissible doses, with the exception of cadmium, which shows a high content compared to that established by [9].

Similarly in algae, the comparison with the standard norms leads to contents of $\mathrm{Fe}$, $\mathrm{Cu}$ and $\mathrm{Zn}$ below international standards, while the levels of $\mathrm{Pb}$ and $\mathrm{Cd}$ are higher than the standards set by [10].

\section{Conclusions}

The coastal ecosystem of Honaïne presents several peculiarities related, firstly to its good ecological status, and secondly, to its isolated position on a long side of all kinds of industrial and agricultural activity.

The process of accumulation of $\mathrm{Fe}, \mathrm{Cu}$ and $\mathrm{Zn}$ in sediment is largely important compared with those relating to both algae (ANOVA 1).

Corallina is an excellent bioaccumulative of $\mathrm{Pb}$; however it recorded the minimum values for $\mathrm{Fe}$ and $\mathrm{Cu}$ andremains in an intermediate position in the case of $\mathrm{Zn}$. In the contrary, ulva is the weakest of biomonitors, in our case.

The PCA allows a synthesis of all the data collected throughout the coast of Honaïne. It is structured by the presence of three distinct matrices (sediment, corallina and ulva), and that this presentation reflects the homogeneity of rehearsals, which ensures the absence of station effect on the distribution of metal contents.

Through the representation of the PCA and the dendrograms, there is a twinning correlation between $\mathrm{Fe}-\mathrm{Cu}$ 
with sediment, $\mathrm{Pb}-\mathrm{Cd}$ with corallina and $\mathrm{Zn}-\mathrm{Ni}$ with ulva.

The assessment of metal bioaccumulation by these metals in these matrices studied revealed the absence of a widespread metal contamination in all stations, compared to guidelines, which indicates a good ecological state generalized the coastline of Honaïne that can be described as reference area.

\section{References}

[1] Morillo, J., Usero, J. and Gracia, I. (2005) Biomonitoring of Trace Metals in a Mine-Polluted Estuarine System (Spain). Chemosphere, 58, 1421-1430. http://dx.doi.org/10.1016/j.chemosphere.2004.09.093

[2] Phillips, D.J.H. (1994) Macrophytes as Biomonitors of Trace Metals. Biomonitoring of Coastal Waters and Estuaries, 85-103.

[3] Davis, T.A., Volesky, B. and Mucci, A. (2003) A Review of the Biochemistry of Heavy Metal Biosorption by Brown Algae. Water Research, 37, 4311-4330. http://dx.doi.org/10.1016/S0043-1354(03)00293-8

[4] Sawidis, T., Brown, M.T., Zachariadis, G. and Sratis, I. (2001) Tracemetal Concentrations in Marine Macroalgea from Different Biotopes in the Aegean Sea. Environment International, 27, 43-47. http://dx.doi.org/10.1016/S0160-4120(01)00052-6

[5] Schintu, M., Marras, B., Durante, L., Meloni, P. and Conti, A. (2010) Macroalgae and DGT as Indicators of Available Trace Metals in Marine Coastal Waters near a Lead-Zinc Smelter. Environmental Monitoring and Assessment, 167, 653-661. http://dx.doi.org/10.1007/s10661-009-1081-8

[6] Topcuoğlu, S., Kiliç, Ö., Belivermiş, M., Ergül, H.A. and Kalayci, G. (2010) Use of Marine Algae as Biological Indicator of Heavy Metal Pollution in Turkish Marine Environment. Journal of the Black Sea/Mediterranean Environment, 16, 43-52.

[7] Kut, D., Topcuoğlu, S., Esen, N., Küçükcezgin, R. and Güven, K.C. (2000) Trace Metals in Marine Algae and Sediment Samples from the Bosphorus. Water, Air, Soil Pollution, 118, 27-33. http://dx.doi.org/10.1023/A:1005149500870

[8] Thomann, R.V., Mahony J.D. and Mueller, R. (1995) Steady-State Model of Biota Sediments Accumulation Factor for Metals in Two Marine Bivalves. Environmental Toxicology and Chemistry, 14, 1989-1998. http://dx.doi.org/10.1002/etc.5620141121

[9] IAEA-433 (2004) International Atomic Energy Agency. Trace Elements and Methylmercury in Marine Sediment. https://www.iaea.org/nael/refmaterial/iaea433.pdf

[10] IAEA-392 (2005) International Atomic Energy Agency. Trace, Minor and Major Elements in Algae. https://nucleus.iaea.org/rpst/.../IAEA-392.htm

[11] Conti, M.E. and Cecchetti, G. (2003) A Biomonitoring Study: Trace Metals in Algae and Molluscs from Tyrrhenian Coastal Areas. Environmental Research, 93, 99-112. http://dx.doi.org/10.1016/S0013-9351(03)00012-4

[12] Marcellin, Y.K., Bernard, S.M., Trokourey, A. and Yobou, B. (2009) Assessment of Sediments Contamination by Heavy Metals in a Tropical Lagoon Urban Area (Ebrié Lagoon, Côte d'Ivoire). European Journal of Scientific Research, 34, 280-289.

[13] El Morhit, M. (2009) Hydrochimie, éléments traces métalliques et incidences écotoxicologique sur les différentes composantes d'un écosystème estuarien Bas Loukkos. PhD Thesis, Mohammed V University, Rabat.

[14] El Sayed, M.A. and Dorgham, M.M. (1994) Trace Metals in Macroalgae from the Qatari Coastal Water. J. King Abdulaziz Univ.: Mar. Sci., 5, 13-24.

[15] Malea, P., Haritonidis, S. and Kevrekidis, T. (1995) Metal Content of Some Green and Brown Seaweeds from Antikyra Gulf (Greece). Hydrobiologia, 310, 19-31. http://dx.doi.org/10.1007/BF00008180

[16] Karez, C.S., Magalhaes, V.F., Pfeiffer, W.C. and Amado Filho, G.M. (1994) Trace Metal Accumulation by Algae in Sepetiva Bay, Brazil. Environmental Pollution, 83, 351-356. http://dx.doi.org/10.1016/0269-7491(94)90157-0

[17] Ergül, H.A., Ay, U., Karademir, A., Cayir, B., Topcuoğlu, S., Telli, B. and Terzi, M. (2010) Heavy Metal Concentrations in Biota, Sediment and Sea Water Samples from Dil Eskelesi Region. In: Topcuoğlu, S., Kiliç, Ö., Belivermiş, M., Ergül, H.A. and Kalayci, G., Eds., Use of Marine Algae as Biological Indicator of Heavy Metal Pollution in Turkish Marine Environment, Journal of the Black Sea/MediterraneanEnvironment, 16, 43-52.

[18] Gopinath, A., Muraleedharan, N.S., Chandramohanakumar, N. and Jayalakshmi, K.V. (2011) Statistical Significance of Bio Monitoring of Marine Algae for Trace Metal Levels in a Coral Environment. Environmental Forensics, 12, 98-105. http://dx.doi.org/10.1080/15275922.2011.547440

[19] Allam, H., Benguedda, W., Aouar, A. and Bettioui R. (2013) Partitionnement des métaux lourds chez l’oursin livide Paracentrotus lividus des eaux côtières de l'extrême ouest algérien. Société Zoologique de France, 138, $251-261$.

[20] Strezov, A. and Nonova, T. (2005) Environmental Monitoring of Heavy Metals in Bulgarian Black Sea Green Algae. 
Environmental Monitoring and Assessment, 105, 99-110. http://dx.doi.org/10.1007/s10661-005-3158-3

[21] Welken, R.D. and Weiller, K. (1987) Behavior of Iron and Manganese in Comparison to Other in Elbs Estuary. International Conference on Heavy Metals in the Environment, 2, 227-229.

[22] Wong, M.H., Kowk, T.T. and Ho, K.C. (1982) Heavy Metals in Ulva lactuca Collected within Tolo Harbour, an Almost Land Locked Sea. Hydrobiological Bulletin, 16, 223-230. http://dx.doi.org/10.1007/BF02255376

[23] Ho, Y.B. (1990) Metals in Ulva lactuca in Hong Kong Intertidal Waters. Bulletin of Marine Science, 47, 79-85.

[24] Akcali, I. and Kucuksezgin, F. (2011) A Biomonitoring Study: Heavy Metals Inmacroalgae from Eastern Aegean Coastal Areas. Marine Pollution Bulletin, 62, 637-645. http://dx.doi.org/10.1016/j.marpolbul.2010.12.021

[25] Mohamed, L.A. and Khaled, A. (2005) Comparative Study of Heavy Metal Distribution in Some Coastal Seaweeds of Alexandria, Egypt. Chemistry and Ecology, 21, 181-189. http://dx.doi.org/10.1080/02757540500151614

[26] Benguedda, W., Dali Youcef, N. and Amara, R. (2011) Trace Metals in Sediments, Macroalgae and Benthic Species from the Western Part of Algerian Coasts. Journal of Environmental Science and Engineering, 15, 1604-1612.

[27] Laib, E. and Leghouchi, E.(2011) Cd, Cr, Cu, Pb, and Zn Concentrations in Ulva lactuca, Codium fragile, Jania rubens, and Dictyota dichotoma from Rabta Bay, Jijel (Algeria). Environmental Monitoring and Assessment, 184, 1711-1718. http://dx.doi.org/10.1007/s10661-011-2072-0

[28] Reinecke, A.J., Snyman, R.G. and Nel, J.A.J. (2003) Uptake and Distribution of Lead (Pb) and Cadmium (Cd) in the Freshwater Crab, Potamonautes perlatus (Crustacea) in the Eerste River, South Africa. Water, Air, \& Soil Pollution, 145, 395-408. http://dx.doi.org/10.1023/A:1023602121272

[29] Balestri, E., Cinelli, F. and Piazzi, L. (1998) Survival and Growth of Transplanted and Natural Seedlings of Posidonia oceanica (L.) Delile in a Damaged Coastal Area. Journal of Experimental Marine Biology and Ecology, 228, 209-225. http://dx.doi.org/10.1016/S0022-0981(98)00027-6

[30] Haritonidis, S. and Nikolaidis, G. (1990) Cd and Zn Uptake in Macrophyceae from Greek Coasts. Biology of Metals, 2, 235-238. http://dx.doi.org/10.1007/bf01141366

[31] Kaimoussi, A., Mouzdahir, A. and Saih, A. (2005) Seasonal Variations of Metal Concentrations (Cd, Cu, Fe, Mn and $\mathrm{Zn}$ ) in Algae Fucus spiralis from the Coast of El Jadida City (Morocco). Water Quality Research Journal of Canada, 40, 102-110.

[32] Scott, G.T. and Hayward, H.R. (1955) Sodium and Potassium Regulation in Ulva lactuca and Valonia macrophysa. In: Shanes, A.M., Ed., Electrolytesin Biological Systems, American Physiological Society, Washington DC, 35-64.

[33] Littler, M.M., Littler, D.S. and Taylor, P.R. (1983) Evolutionary Stages in a Tropical Barrier Reef System: Functional-Form Groups of Marine Macroalgae. Journal of Phycology, 19, 229-237. http://dx.doi.org/10.1111/j.0022-3646.1983.00229.x

[34] Jordanova, A., Strezov, A., Ayranov, M., Petkov, N. and Stoilova, L. (1999) Heavy Metal Assessment in Algae, Sediments and Water from the Bulgarian Black Sea Coast. Water Science \& Technology, 39, 207-212. http://dx.doi.org/10.1016/S0273-1223(99)00204-8

[35] Alam, L., Mohamed, C.A. and Bin Mokhtar, M. (2012) Accumulation Pattern of Heavy Metals in Marine Organisms Collected from a Coal Burning Power Plant Area of Malacca Strait. Science Asia, 38, 331-339. http://dx.doi.org/10.2306/scienceasia1513-1874.2012.38.331 